\title{
Organochlorine compounds in sediment core of subarctic small lake
}

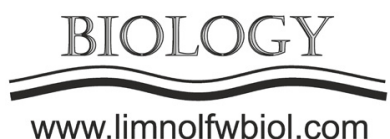

\author{
Velyamidova A.V.*, Kolpakova E.S. \\ N. Laverov Federal Center for Integrated Arctic Research of the Ural Branch of the Russian Academy of Science, Northern Dvina Emb., \\ 23, Arkhangelsk, 163000, Russia
}

\begin{abstract}
The paper is dedicated to the study of organochlorines behavior under specific conditions of the lake ecosystem of the northernmost location of the exit of thermal-mineral springs in the continental Europe, Pymvashor natural boundary (Bolshezemelskaya Tundra, Nenets Autonomous Okrug). Data on the quantitative content, distribution characteristics and composition of organochlorines in lake sediments were first obtained for given location. The presence of chlorophenol compounds (up to 766 $\mathrm{ng} \mathrm{g}^{-1}$ d.w.) in the sediments was due to the occurrence of natural enzymatic and biochemical processes in the components of lake ecosystems. Due to the remoteness of the study area, the presence and levels of persistent organochlorine pollutants (pentachlorophenol 0.1-2.4 $\mathrm{ng} \mathrm{g}^{-1} \mathrm{~d}$.w., polychlorobenzenes 0.4-3.6 $\mathrm{ng} \mathrm{g}^{-1} \mathrm{~d}$.w.) in the lake sediments were associated with long-range atmospheric transport in the past and in the present time.
\end{abstract}

Keywords: organochlorines, sediment core, small lake, subarctic hydrothermal system.

\section{Introduction}

The natural ecosystems of the Arctic and Subarctic are characterized by poor resistance to any type of impact and extremely slow recovery rate. The environment of these high-latitude regions is influenced by regional and remote anthropogenic (industry-related) sources; among their emissions organochlorine compounds occupy a special place. In general, organochlorines are widespread in the environment; their sources are not only industrial production and application, but also natural processes (thermal, enzymatic, biochemical) (Gribble, 2010). High-latitude small lakes as ecosystems with slower water exchange are effective natural "reservoirs" for various compounds coming from the atmosphere, collected from the catchment areas and formed in the water body, which accumulate and "conserve" in the bottom sediments (BS). These lakes can be considered as natural model objects to study the means of forming the levels of contents and the composition of organochlorines, as well as the processes of their transformation and degradation in the components of aquatic ecosystems. This paper presents the results that are part of the studies of Bolshezemelskaya Tundra aquatic ecosystems (using the small lake in the valley of Pymvashor natural boundary, Adzva river basin, Nenets Autonomous Okrug, as an example).

\section{Materials and methods}

The study area is located in remote, hardto-reach, and almost uninhabited tundra region, therefore the anthropogenic (industry-related) load is expressed weakly; and Pymvashor natural boundary was preserved in a slightly disturbed state as the whole complex of natural aquatic and terrestrial ecosystems. In general, the regional climate is typically arctic: a long cold winter, a short vegetation season, and a large amount of rainfall. A feature of natural conditions is the presence of permafrost.

The studied lake is located in the valley of subarctic Pymvashor natural boundary; it is small, shallow (depth no more than 1-2 m), thermokarst, and swampy, highly overgrowing lake. Sampling was carried out by the employees of the N. Laverov Federal Center during a combined expedition in September 2010. The lake sediment core (thickness of BS is $36 \mathrm{~cm}$ ) was collected using a shock coring tube. An optimized sample preparation and analysis scheme was used to determine the target organochlorines (chlorophenol compounds, polychlorobenzenes, including hexa- and pentachlorobenzenes) from one BS sample (Kolpakova et al., 2019). Analytical quantification and identification of individual organochlorine compounds was carried out by the method of capillary GC/ECD. The detection limit was $0.1 \mathrm{ng} \mathrm{g}^{-1} \mathrm{~d}$.w. Elemental analysis (specifically $\mathrm{C}_{\text {org }}$ ) was carried out using the Euro EA 3000 automatic

*Corresponding author.

E-mail address: allavel@yandex.ru (A.V. Velyamidova) 
elemental analyzer. Particle size distribution of BS samples was determined in accordance to MI No. 8816365-010-2017.

\section{Results and discussion}

Chlorophenols (CPs) and their derivatives were identified in all layers of the lake sediment core; but the highest levels of CPs (114-766 ng g-1 d.w.) were found in the upper $(0-15 \mathrm{~cm})$ layers. Low chlorinated phenols (mainly monochlorinated) predominated in the CPs composition (98\%). These compounds can be formed as a result of enzymatic and biochemical processes of dechlorination of polychlorophenols in the environment (Gribble, 2010), which happened due to favorable conditions for their occurrence. The low levels of CPs (1.1-13.2 $\mathrm{ng} \mathrm{g}^{-1}$ d.w.) were found in the sublayers $(15-36 \mathrm{~cm})$ with the domination of highly chlorinated phenols (mainly tri- and tetrachlorinated).

Pentachlorophenol(PCP) and polychlorobenzenes (PCBzs), highly toxic compounds from the list of persistent organic pollutants (POPs), are also identified in all layers of the lake sediment core. Moreover, the amount of hexachlorobenzene exceeded the amount of other analyzed POPs. The highest total amounts of PCBzs (1.8-3.6 $\mathrm{ng} \mathrm{g}^{-1}$ d.w.) and levels of PCP (1.7-2.2 $\mathrm{ng} \mathrm{g}^{-1}$ d.w.) were found in the upper layers (fibrous aleuriticpelitic organic rich mud, $\mathrm{C}_{\text {org }} 37.74-47.62 \%$ ) of the sediment core. These BS layers were deposited during the "chemical/chlorine" period of industrial development. The total amounts of PCBzs notably decreased (to 0.4$1.7 \mathrm{ng} \mathrm{g}^{-1} \mathrm{~d}$.w.), and PCP was encountered occasionally in the sublayers when the sediment type changed to poor in organic matter $\left(\mathrm{C}_{\text {org }} 1.76-5.64 \%\right)$ clay mud with sand. The high sedimentation rate (on average $2 \mathrm{~mm}$ year $^{-1}$ ) in the studied lake (Shevchenko et al., 2017) suggested a relatively weak mineralization and gradual burial of organic matter in BS. These factors could contribute to the accumulation and "conservation" of organochlorines which can be actively sorbed by organic matter in BS. The presence of some specific organochlorine compounds (especially POPs) in sediment layers deposited at an earlier time period (from the first third of the 19th to early 20th century) is most likely due only to the emission from thermal sources: natural (e.g., forest fires) and industry-related (fossil-fuel combustion and wood burning, industrial thermal processes, etc.). The revealed levels of specific organochlorines in the absence of located nearby sources of emission suggest long-range atmospheric transport as the most likely route of entry into sediments.

\section{Conclusions}

The first data on the specifics of the biogeochemical processes with the participation of organochlorines in the small lake ecosystem of the subarctic hydrothermal system are obtained. In the lake sediment core, a tendency toward a decrease in the organochlorines levels in depth, due to both the lithological features of bottom sediments and the specific features of emission sources, is revealed. The presence and levels of persistent organochlorine pollutants in the sediments are most likely the result of transfer with air masses from various sources in nearby regions and low-latitude territories.

\section{Acknowledgments}

This work was carried out at the expense of Minobrnauki of Russia, project No. AAAA-A18-118012390167-1.

The authors thank all employees of the $\mathrm{N}$. Laverov Federal Center for Integrated Arctic Research (Arkhangelsk) who participated in the sampling, transportation of sediments samples, and performance of some analyzes of bottom sediments.

\section{References}

Gribble G.W. 2010. Naturally occurring organohalogen compounds - a comprehensive update. Wien/New York: Springer-Verlag Wien, $613+\mathrm{XV}$ p.

Kolpakova E.S., Velyamidova A.V., Shvetsova N.V. et al. 2019. Organochlorine compounds in freshwater ecosystems of the Arctic territories. In: Vserossiyskaya Konferentsiya $s$ Mezhdunarodnym Uchastiyem "II Yudakhinskiye Chteniya" [All-Russian conference with international participation "II Yudakhin Readings"], pp. 295-298. (in Russian) 